\title{
Measuring Customer Satisfaction for Customer Relationship Management Activities Perform by Indian Commercial Banks in Surat City
}

\author{
Shaileshkumar Jausukhbhai Limbad ${ }^{1}$ and Vinod Patel ${ }^{2}$ \\ ${ }^{1}$ Assistant Professor, Shree JDG Com College and SAS College of Management, Surat, Gujarat, India. \\ ${ }^{2}$ Professor, Department of Business and Industrial Management, VNSGU, Surat, Gujarat, India. \\ E-mail: shailesh.limbad1987@gmail.com
}

\begin{abstract}
The primary purpose of this paper is to measure customer satisfaction for CRM activities perform by Indian Commercial Banks in Surat city. The other purpose is to measure overall customer satisfaction with the services provided by top 3 Indian private and top 3 Indian public commercial banks in Surat. Qualitative methods were used to develop the scope of research to study customer perception. This research study is descriptive in nature. The most appropriate method for selecting the target population is the sampling method of non-probability comfort followed by stratified sampling technique. Of the 1,200 questionnaires distributed, 973 questionnaires were finally considered to correctly analyze the data. Appropriate statistical tools and techniques were used for the research study. Factors were found to differentiate performance based on types of banks. For the reliability of private banks, the response elements and the marketing mix have a great relationship with overall satisfaction, as well as an important relationship between overall customer satisfaction and loyalty. For public sector banks, there is an important relationship between the elements of collateral and the marketing mix, the overall satisfaction of customers, and the overall satisfaction and loyalty. ICICI is the leading bank in terms of performance from a customer perspective and among the public sector bank BOB (Bank of Baroda) which has performed much better than other banks. With the researcher the researcher tries to establish a relationship between customer satisfaction and effective management of the customer relationship. The researcher concludes that for some factors, there is an important relationship between CRM and overall customer satisfaction and an increase in the customer base. Therefore, the management of banks is encouraged to implement CRM programs so that they can take advantage of the current competitive business environment.
\end{abstract}

Keywords: CRM, Overall customer satisfaction, Indian banking industry

\section{INTRODUCTION}

Business always starts and ends with customers, so customers should be treated as the king of the market. All improvements in business, profits, status, image etc. of the enterprise depend on customers. It is therefore important that all organizations meet the expectations of all customers and determine customer satisfaction. Customer satisfaction is a measure of how to deliver collaboration between needs and responses to meet customer expectations. This can only be achieved if the customer has a good public relationship with the supplier. In today's competitive business market, customer satisfaction is an important performance exhibitor and an essential feature of business strategies. Therefore, the greater the customer satisfaction. The greater the company and the bond with the client. Customer satisfaction is part of the customer experience that exposes supplier behavior to customer expectations. It also depends on how effectively and quickly they deliver the services. This satisfaction can be linked to many aspects of business such as marketing, product manufacturing, engineering, quality of products and services, responses to customer problems and requests, project completion, post-delivery services, claims management, etc. Customer satisfaction is the general essence of customer impression on supplier.

This customer experience of the provider represents the total of all transactions they spend, from the pre-marketing contact provider to post-delivery options and services and the management of orders or complaints after delivery. During this process, the client meets the working environment of different departments and the type of strategies involved in the organization. This helps the customer to have a strong opinion on the supplier, ultimately leading to satisfaction or dissatisfaction. Customer vision of the seller helps the seller to choose based on the dollar value and how the delivered products meet all requirements. Vendor services do not retreat after delivery because the customer is looking for high values after marketing services, which may help them to use the delivered product and deliver it more effectively.

If you are satisfied with post-marketing services, there is a good opportunity for the supplier to retain customers to optimize repeat purchases and make good profits. It is essential that the organization interact and communicate regularly with customers to increase customer satisfaction. In these interactions and communications, it is necessary to learn and identify all the individual needs of customers and respond to it. Although products are identical in competing markets, satisfaction provides high retention rates. For example, buyers and retailers usually make purchases and credit cards to satisfy their customers. Many premium retailers also offer membership cards and discounts on these cards to keep the customer honest. 
The higher the level of satisfaction leads to the greater the emotional attachment of customers to the product and supplier's brand. This helps establish a strong and healthy connection between the customer and the vendor. This link forces the customer to link to this particular provider and the chances of cracking are much lower. Therefore, customer satisfaction is a very important panorama that every supplier must focus on to create a site to abandon in the global market and improve business and profit.

\section{LITERATURE REVIEW}

Kumar Mukesh et al. (2009), a study was conducted to determine the critical factors to reach the level of service quality in banks by reviewing the SERVQUAL model (which was originally pioneered by Parasuraman) and measuring the relative importance of each critical factor in bridging the banks' overall service quality gap. For this purpose, 308 bank customers were contacted using a structured questionnaire on a 7-point scale. The researcher discovered that the modified SERVQUAL model consists of four critical factors (dimensions such as tangibility, reliability, efficiency, and comfort. Second, there are statistically significant differences between participants' expectations and perceptions.

Dhar Ravi K. et al. (2009), a study was conducted to track factors that influence customer expectations and perceptions regarding the quality of banking. Preliminary data were collected with a convenience sampling method of 240 usable respondents on a likert scale of 7 points. They discovered that in the face of intense competition in global business where companies must stay and grow on a scale rather than a margin, the quality of service will form the basis for marketing services. Public sector banks should focus on reducing the gap in customer expectations and perceptions about the quality of their services if they are to compete in the global market, they said. Public sector banks should continually evaluate and reassess how customers perceive their services and evaluate the implementation of appropriate corrective actions to retain existing clients and acquire clients.

Mylonakis John (2009) conducted a study to examine the level of customer satisfaction of Greek banks based on their experiences and perceptions of banks, as well as their buying behavior and attitudes towards banking products and services offered. Random samples were collected from 182 bank clients using large-scale structured questionnaires. Research indicates that the majority of the bank's customers are satisfied with the bank they are cooperating with and that the friends or relatives who work at the bank are the most important factor, followed by a large network of branches and friend recommendations. Competition levels and a variety of offers and alternative solutions provide a new tool in the hands of customers if they are not satisfied: change their bank. They also found that customers want their banks to be technically sophisticated to execute transactions and take advantage of fast customer service, and even prefer the traditional face-to-face approach where they go to buy banking.

Ramkelawon Bhisham (2010), a proposed study to analyze whether banks are already implementing the concept and philosophy of CRM in full to ensure competitive advantage. Exploratory and descriptive research was used where different aspects of CRM were extracted in the banking sector. To support experimental research, both quantitative and qualitative data were used in completing the survey and included both secondary and primary data. The survey included both employees and customers as a sample. He proposed a model illustrating the specific problems banks need to address in order to use CRM as an integrated approach to gaining competitiveness in the banking sector. The bank is far from developing a client approach to customers as well as to employees. Therefore, in order for CRM to meet its expectations, it must play a complementary role within the Bank and ensure that all operations are integrated into the Bank's global strategy, which is far from reality. Instead of focusing on developing product strategies, banks can offer customers by having concise and accurate ways to do things through effective customer relationship management.

Munusamy Jayaraman (2010), a proposed study focused on measuring customer satisfaction by providing high quality service in the banking sector in Malaysia. Quantitative research was used to study the relationship between the dimensions of quality of service and customer satisfaction. The survey questionnaire was designed and distributed to 117 people randomly on a 5-point scale. The study found that the affirmation has a positive relationship but does not have a significant impact on customer satisfaction, reliability has a negative relationship but does not have a significant impact on customer satisfaction and tangible relationships have a positive relationship and a significant impact on customer satisfaction and to empathy positive relationship but not a significant impact. Customer satisfaction and response have a positive relationship but not a significant impact on customer satisfaction.

Clemes Michael D. et al (2010) conducted a study to identify and analyze factors that influence the behavior of bank customers in retail banking in China. They used a suitable sample of 421 bank customers in Jiaozuo City, Henan Province, China. They used a questionnaire developed based on the findings of the literature review and the comments received from the focus groups. The search results reveal that price, reputation, quality of service, effective advertising, involuntary switching, remote switching, and cost affect the customer's bank transfer behavior. Second, youth and high-income groups are likely to switch banks. This research reveals that the decrease in unit conversion costs has the greatest impact on the likelihood of a client turning to banks. Price is another important factor affecting the marginal probability of transferring customers to banks. Quality of service is an important factor affecting the marginal probability of bank 
transfer behavior of customers. A good reputation plays an important role in creating positive signals to the public about a company's ability and reliability. Bank managers should develop effective advertising strategies that enhance communication channels between customers and their banks and encourage new customers from other banks. Distance to favourable branches can play an important role in influencing customers who care more about convenience because it allows them to save time. Involuntary switching (such as moving home, changing jobs, opening, or closing a bank branch) is an important factor affecting the marginal probability of interbank switching.

Ganguly Shirshindo et al. (2011), a proposed study to determine the dimensions of public service quality of technology-based banking and study the impact of these dimensions on customer satisfaction and customer loyalty. The research collected data through an online questionnaire from undergraduate students at a University of Massachusetts in the United States using the seven-point Likert scale, which ranges from "Strongly Disagree" to "Strongly Agree." The study identifies four dimensions of public service quality in service-based banking technology customer service, technology security, information quality, technological comfort, ease of use and technological reliability. It has been found that customer service, ease of use of technology and reliability have a positive and significant impact on customer satisfaction and customer loyalty. Technology comfort and customer satisfaction have also been found to have a significant and positive impact on customer loyalty.

Pambhar Vijay. M. (2011), a proposed study to assess the impact of service quality dimensions, brand perception and perceived value on customer satisfaction in e-banking? To conduct the customer survey, a questionnaire-based questionnaire was developed after reviewing the literature and discussions with bank managers as well as experts in customer service and marketing. Respondents were selected using the estimated sampling method. Discover that perceived value, brand awareness, cost-effectiveness, ease of use, convenience, problem-solving, security / warranty and response are important factors in customer satisfaction. Communication facilities, system availability, fulfillment, efficiency and compensation are relatively less important. Response, ease of use, cost-effectiveness and compensation are factors that predict the brand's perception of e-banking, loyalty, effectiveness, security / security, responsiveness, convenience, cost-effectiveness, problem-solving and compensation, and are indicators of perceived value in electronic banking.

Ramadan Mohamed Ali and others. (2011), proposed study to determine the impact on the quality of services in the Islamic banking sector in Indonesia. They adopted investigative research by distributing questionnaires using a likert placement scale to 184 participants and a methodology for systematic random sampling. They found that quality of service is a commitment to banks. The physical dimension proved to be the least impact of QoS. The bank should start looking at the indicators that make up this dimension and then achieve it, such as adding a number of cashiers who according to research results, most customers claimed that the figure was not enough. While the dimensions that should start forming satisfaction is to enhance the speed of transactions or the speed of transactions between customers and employees.

Singh Volbagh et al. (2011), a study was conducted to analyze customer perception of service quality in rural and urban bank branches and their impact on customer satisfaction. The researcher used a randomized convenience sampling method to collect data and data collected from 170 bank clients through a questionnaire with a scale like 5 points. The study identifies six service quality factors that affect customer satisfaction regarding banking services. The analysis shows that the level of satisfaction of rural customers is higher compared to urban customers. It can be concluded from the analysis that all six factors have a positive effect on overall customer satisfaction, but the effect of concrete is not statistically significant.

\section{RESEARCH METHODOLOGY}

There are some research gaps in measuring the effectiveness of CRM in the past, with reference to their recent applications in today's banking institutions. Several studies have been conducted on several aspects, but the dynamic aspects of CRM practices make them older. The aim of this research study is to measure customer perception of the CRM practices applied by various Indian commercial banks; therefore, the researcher attempts to evaluate the different models and relationship between different service parameters of CRM.

Problem statement: Fierce competition between retail banks in India and all banks realized the need to protect their existing customer base. Maintaining customer relationship and building customer loyalty has become a business strategy, as banks recognize that the value of a customer's life determines the value of a long-term relationship.

\section{A. Problem Statement:}

To what extent has the banking relationship affected the loyalty of customers in Indian commercial banks in Surat?

\section{B. Objectives}

1. To measure customer satisfaction for CRM activities, perform by Indian commercial banks in Surat city.

2. To measure overall customer satisfaction with the services provided by top 3 Indian private and top 3 Indian public commercial banks in Surat. 


\section{Research Design}

This research study is descriptive in nature and attempts to examine perception of CRM practices in the Indian banking sector with specific reference to the first three banks in the public sector category and three months in the private sector category. A structured questionnaire survey was used to collect data for this research, and this process was administered by conducting interviews.

\section{Sampling Design \\ 1. Study Population}

The target population will be the population residing in the six areas of Surat. The target population for this specific research to include the bank's client belongs to the three largest private banks and three public sector banks in Surat.

\section{Sampling Method}

The most suitable method for selecting the target group is sampling method of non-probability comfort followed by stratified sampling method.

\section{Sampling Area}

Respondents are from Surat city. The entire city of Surat was divided into six districts, each with 200 districts and 1,200 questionnaires were distributed in full.

Sample size: Participants were selected from the top three private sector banks and three public sector banks in Surat. Of the questionnaire distributed, a total of 1,125 questionnaires were returned, and at the data entry stage, some unfilled or incomplete questionnaires were not considered for data analysis and interpretation. Finally, 973 questionnaires were considered to correctly analyze the data.

\section{Method of Data Collection}

Secondary data collection: Secondary data were collected through the Internet, studying previous scientific articles from libraries and universities. It includes books, academic journals, websites, previous research theses, government publications, and published and unpublished materials consisting of booklets, pamphlets, booklets, manual notes, project reports, etc. RBI and many CRM sites have a very useful information source. Preliminary data collection: A total of 1,200 clients from all banks surveyed and interviewed to see their perceptions. Bank customers were surveyed through a structured questionnaire using a fivepoint assessment scale of strongly disagree with the agreement, which the researcher personally administers. The sample of the client is fixed based on the researcher's convenience taking into account the lack of time and resources.

\section{Data Analysis}

Appropriate statistical tools and techniques were used for the research study. The use of different statistical methods to analyze data depends on the type of data to be collected. Thus, accurate statistical tests such as reliability analysis, kruskal wallis testing, and structural equation modeling were used after data collection. SPSS and AMOS were used for statistical analysis of data.

\section{DATA ANALYSIS AND FINDINGS}

\section{A. Reliability Analysis}

Reliability refers to the extent to which a scale produces consistent results, if the measurements are repeated several times.

TABLE 1 RELIABILITY ANALYSIS: CRONBACH'S ALPHA

\begin{tabular}{|l|c|c|}
\hline \multirow{2}{*}{\multicolumn{1}{|c|}{ Particulars }} & \multicolumn{2}{c|}{ Cronbach's Alpha } \\
\cline { 2 - 3 } & Private banks & Public banks \\
\hline Tangibility elements & .85 & .88 \\
\hline Reliability elements & .78 & .76 \\
\hline $\begin{array}{l}\text { Responsiveness } \\
\text { elements }\end{array}$ & .74 & .65 \\
\hline Assurance elements & .79 & .73 \\
\hline Empathy elements & .81 & .73 \\
\hline Trust elements & .70 & .80 \\
\hline Convenience elements & .81 & .80 \\
\hline $\begin{array}{l}\text { Technological } \\
\text { elements }\end{array}$ & .80 & .74 \\
\hline Cultural elements & .80 & .67 \\
\hline Marketing elements & .80 & .83 \\
\hline
\end{tabular}

Alpha values were described as excellent (0.93-0.94), strong (0.91-0.93), reliable (0.84-0.90), strong (0.81), fairly high (0.76-0.95), high (0.73-0.95), good ( 0.71-0.91), Relatively High (0.70-0.77), Slightly Low (0.68), Reasonable (0.670.87), Relevant (0.64-0.85), Average (0.61-0.65), Acceptable (0.58-0.97), Acceptable (0.45) -0.98)), adequate (0.45-0.96), unsatisfactory (0.4-0.55) and low (0.11).

\section{B. Structure Equation Modeling}

The study proposed the Structural Equation Model (SEM) to describe the relationship between overall customer satisfaction and CRM practices, and to define the perception of services provided by the bank by their customers. The appropriateness of the model was assessed using the Fit Fit Index (GFI), Incremental Fit Index (IFI), Standard Fit Index (NFI), Comparative Fit Index (CFI), and RMSEA. All the above criteria meet the recommended level $(\mathrm{GFI}=0.938$, $\mathrm{IFI}=0.958, \mathrm{NFI}=0.957, \mathrm{CFI}=0.958, \mathrm{RMSEA}=0.220)$ to fit reasonably well. Chi-square was used to test the proposed relationship. In addition to the kai-square test and its associated p-values, the comparative phi-t index (CFI), the ph-normed t-index (non-food), the non-normed phi-tindex (NNFI), and the root mean square residue (RMR), tests are used to fit the model . 
TABLE II MODEL FIT INDEX- PRIVATE BANKS

\begin{tabular}{|c|c|l|}
\hline Chi-square & 240.354 & \\
\hline RMR & 0.028 & $\begin{array}{l}\text { RMR near to zero indicate a perfect fit. The smaller } \\
\text { the RMR is the better. }\end{array}$ \\
\hline RMSEA & 0.220 & Good models have small RMSEA. \\
\hline GFI & 0.938 & Values of 0.90 or greater indicate well-fitting models. \\
\hline NFI & 0.957 & Values greater than 0.90 indicating a good fit. \\
\hline CFI & 0.958 & Values greater than 0.90 indicating a good fit. \\
\hline IFI & 0.958 & Values greater than 0.90 indicating a good fit. \\
\hline TLI & 0.722 & Values greater than 0.90 indicating a good fit. \\
\hline
\end{tabular}

TABLE III. SEM PARAMETER ESTIMATIONS- PRIVATE BANKS

\begin{tabular}{|c|c|c|c|c|c|c|}
\hline & & & Estimate & P & Result & Supported \\
\hline PROVRLAV & $<---$ & PRTANGAV & $\mathbf{- . 0 5 1}$ & .321 & Insignificant & No \\
\hline PROVRLAV & $<---$ & PRRELAV & $\mathbf{- . 1 1 0}$ & .050 & Significant & Yes \\
\hline PROVRLAV & $<---$ & PRRESAVE & $\mathbf{. 5 8 7}$ & $* * *$ & Significant & Yes \\
\hline PROVRLAV & $<---$ & PRASSUAV & $\mathbf{. 0 3 2}$ & .411 & Insignificant & No \\
\hline PROVRLAV & $<---$ & PREMPAV & $\mathbf{. 0 3 2}$ & .441 & Insignificant & No \\
\hline PROVRLAV & $<---$ & PRTRUAV & $\mathbf{. 0 4 7}$ & .235 & Insignificant & No \\
\hline PROVRLAV & $<---$ & PRCONAV & $-\mathbf{. 0 0 8}$ & .834 & Insignificant & No \\
\hline PROVRLAV & $<---$ & PRTECAV & $\mathbf{- . 0 1 9}$ & .615 & Insignificant & No \\
\hline PROVRLAV & $<---$ & PRCULAV & $\mathbf{. 0 1 5}$ & .758 & Insignificant & No \\
\hline PROVRLAV & $<---$ & PRMKTAV & $\mathbf{. 3 9 1}$ & $* * *$ & Significant & Yes \\
\hline PRLOYAV & $<---$ & PROVRLAV &. $\mathbf{7 5 7}$ & $* * *$ & Significant & Yes \\
\hline
\end{tabular}

In this study, "reliability", "response elements" and "marketing mix elements" were found as the most important estimate and the most important customer satisfaction in general. Customer satisfaction in general has a significant impact on loyalty to private banks. For example, the tangible path factor for overall customer satisfaction is 0.051. This value indicates that for each unit of increase in
CRM practices, its effects will contribute to a -0.051 unit increase in customer satisfaction. Importantly, the effects of QoS on customer satisfaction are not significant ( $\mathrm{p}<0.001)$. Thus, the hypothesis that quality of service has significant and positive effects on customer satisfaction is not supported.

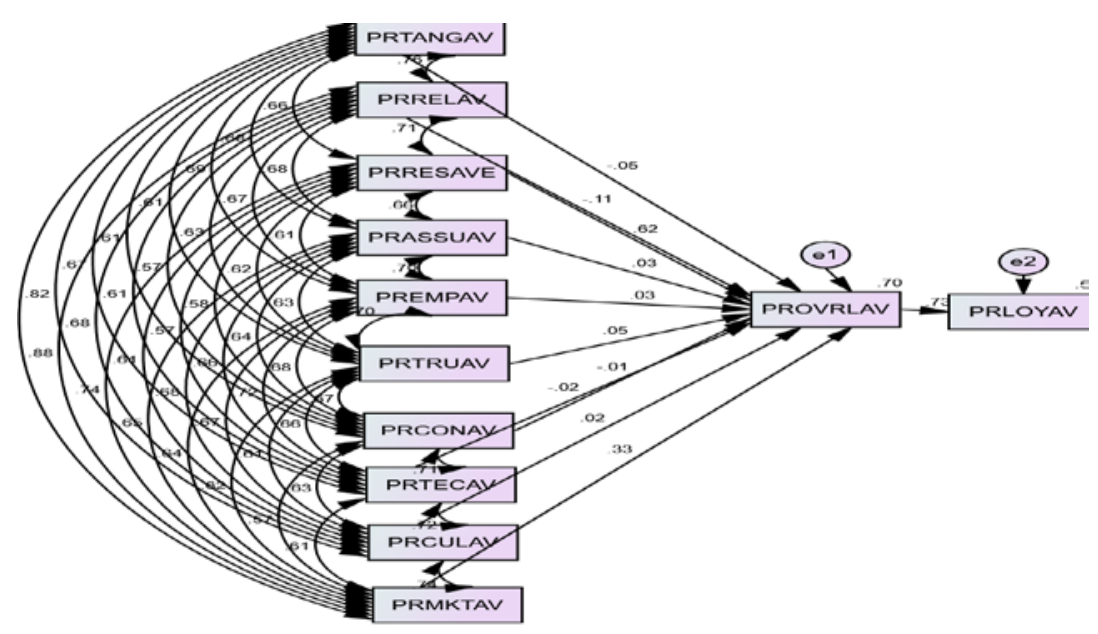

Fig. 1 Sem Model for Private Banks 
TABLE IV MODEL FIT INDEX- PUBLIC BANKS

\begin{tabular}{|c|c|c|}
\hline Chi-square & 375.527 & \\
\hline RMR & 0.046 & $\begin{array}{r}\text { RMR near to zero indicate a perfect fit. The smaller the } \\
\text { RMR is the better. }\end{array}$ \\
\hline RMSEA & 0.277 & Good models have small RMSEA. \\
\hline GFI & 0.917 & Values of 0.90 or greater indicate well-fitting models. \\
\hline NFI & 0.917 & Values greater than 0.90 indicating a good fit. \\
\hline CFI & 0.918 & Values greater than 0.90 indicating a good fit. \\
\hline IFI & 0.919 & Values greater than 0.90 indicating a good fit. \\
\hline TLI & 0.456 & Values greater than 0.90 indicating a good fit. \\
\hline
\end{tabular}

The appropriateness of the model was assessed using the Fit-Fit Index (GFI), Incremental Fit Index (IFI), Standard Fit Index (NFI), Comparative Fit Index (CFI), and Root Medium Error (RMSEA).
All the above criteria meet the recommended level (GFI = 0.917 , IFI $=0.919$, NFI $=0.917$, CFI $=0.918$, RMSEA $=$ 0.277 ) to fit reasonably well.

TABLE V SEM PARAMETER ESTIMATIONS- PUBLIC BANKS

\begin{tabular}{|l|l|l|c|c|l|c|}
\hline & & & Estimate & \multicolumn{1}{c|}{ P } & Result & Supported \\
\hline PBOVALAV & $<---$ & PBTANAV & $\mathbf{. 0 5 6}$ & .232 & Insignificant & No \\
\hline PBOVALAV & $<---$ & PBRELAV & $\mathbf{- . 0 1 6}$ & .822 & Insignificant & No \\
\hline PBOVALAV & $<---$ & PBRESAV & $\mathbf{- . 0 1 0}$ & .859 & Insignificant & No \\
\hline PBOVALAV & $<---$ & PBASSUAV & $\mathbf{. 6 8}$ & $* * *$ & Significant & Yes \\
\hline PBOVALAV & $<---$ & PBEMPAV & $\mathbf{. 0 6 9}$ & .275 & Insignificant & No \\
\hline PBOVALAV & $<---$ & PBTRUAV & $\mathbf{- . 0 7 2}$ & .179 & Insignificant & No \\
\hline PBOVALAV & $<---$ & PBCONVAV & $\mathbf{. 0 4 4}$ & .454 & Insignificant & No \\
\hline PBOVALAV & $<---$ & PBTECHAV & $\mathbf{- . 0 0 8}$ & .880 & Insignificant & No \\
\hline PBOVALAV & $<---$ & PBCULAV & $\mathbf{. 0 5 7}$ & .415 & Insignificant & No \\
\hline PBOVALAV & $<---$ & PBMKTAV & $\mathbf{. 3 9 8}$ & $* * *$ & Significant & Yes \\
\hline PBLOYAV & $<---$ & PBOVALAV & $\mathbf{. 5 7 6}$ & $* * *$ & Significant & Yes \\
\hline
\end{tabular}

In the present study, “Assurance", and "Marketing mix elements" were found to be the most important and significant estimator of overall customer satisfaction.
And overall customer satisfaction is also having significant impact on loyalty for public sector banks.

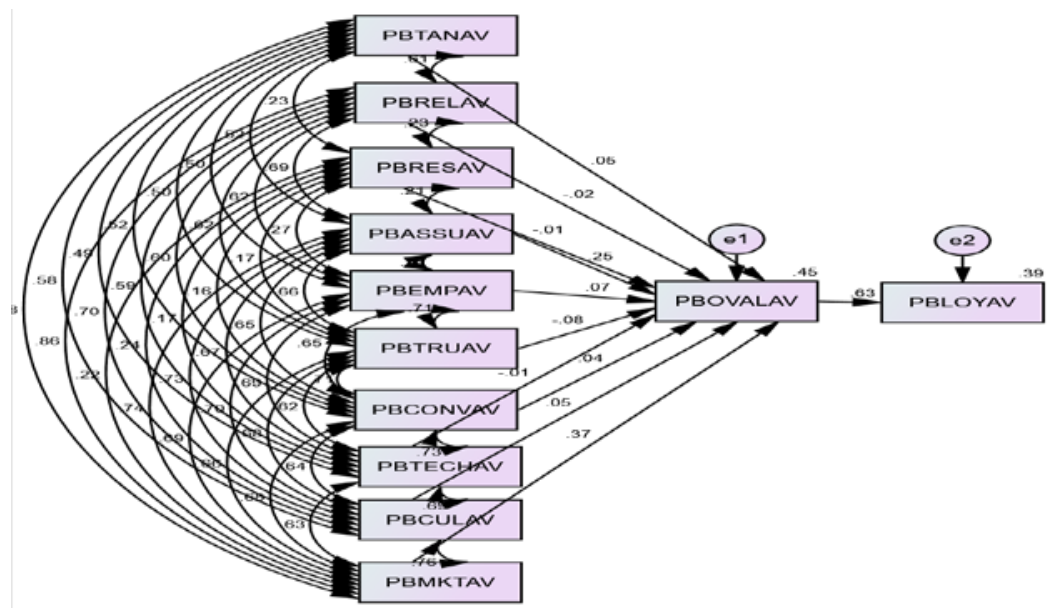

Fig 2 SEM model for public banks 


\section{MEAN STATISTICS: BANK WISE AVERAGE STATISTICS}

TABLE VI BANK WISE AVERAGE STATISTICS

\begin{tabular}{|c|c|c|c|c|c|c|}
\hline Particulars & HDFC & AXIS & ICICI & SBI & ВOB & PNB \\
\hline TANGIBILITY 1 & 4.35 & 4.34 & 4.4 & 3.79 & 3.96 & 3.78 \\
\hline TANGIBILITY 2 & 4.07 & 4.08 & 4.23 & 3.8 & 4.01 & 3.81 \\
\hline TANGIBILITY 3 & 4.13 & 4.08 & 4.27 & 3.88 & 3.98 & 3.79 \\
\hline TANGIBILITY 4 & 4.17 & 4.22 & 4.26 & 3.87 & 3.94 & 3.76 \\
\hline TANGIBILITY 5 & 4.13 & 3.98 & 4.23 & 3.78 & 3.96 & 3.74 \\
\hline TANGIBILITY 6 & 4.03 & 4.06 & 4.31 & 3.81 & 3.91 & 3.76 \\
\hline TANGIBILITY AVERAGE & 4.147 & 4.127 & 4.283 & 3.822 & 3.96 & 3.773 \\
\hline RELIABILITY 1 & 4.13 & 4.2 & 4.32 & 3.64 & 4.06 & 3.72 \\
\hline RELIABILITY 2 & 4.15 & 4.27 & 4.23 & 3.65 & 3.94 & 3.6 \\
\hline RELIABILITY 3 & 4.04 & 4.07 & 4.2 & 3.56 & 3.78 & 3.48 \\
\hline RELIABILITY 4 & 4.07 & 4.18 & 4.34 & 3.61 & 3.92 & 3.62 \\
\hline RELIABILITY 5 & 3.95 & 4.1 & 4.2 & 3.53 & 3.76 & 3.48 \\
\hline RELIABILITY AVERAGE & 4.068 & 4.164 & 4.258 & 3.598 & 3.892 & 3.58 \\
\hline RESPONSIVENESS 1 & 3.94 & 4.05 & 4.14 & 2.81 & 2.93 & 2.86 \\
\hline RESPONSIVENESS 2 & 3.93 & 4.08 & 4.24 & 2.77 & 2.85 & 2.83 \\
\hline RESPONSIVENESS 3 & 4.13 & 4.17 & 4.22 & 2.76 & 2.69 & 2.76 \\
\hline RESPONSIVENESS 4 & 4.11 & 4.12 & 4.23 & 2.76 & 2.65 & 2.78 \\
\hline $\begin{array}{l}\text { RESPONSIVENESS } \\
\text { AVERAGE }\end{array}$ & 4.028 & 4.105 & 4.208 & 2.775 & 2.78 & 2.808 \\
\hline ASSURANCE 1 & 4.07 & 4.12 & 4.16 & 3.64 & 3.96 & 3.57 \\
\hline ASSURANCE 2 & 4.11 & 4.15 & 4.12 & 3.63 & 3.97 & 3.53 \\
\hline ASSURANCE 3 & 3.94 & 4.02 & 4.07 & 3.48 & 3.64 & 3.41 \\
\hline ASSURANCE 4 & 3.93 & 4.02 & 4.06 & 3.46 & 3.69 & 3.47 \\
\hline ASSURANCE 5 & 4.02 & 4.12 & 4.09 & 3.54 & 3.85 & 3.38 \\
\hline ASSURANCE AVERAGE & 4.014 & 4.086 & 4.1 & 3.55 & 3.822 & 3.472 \\
\hline EMPATHY 1 & 4.13 & 4.15 & 4.13 & 3.51 & 3.68 & 3.39 \\
\hline EMPATHY 2 & 4.11 & 4.22 & 4.3 & 3.61 & 3.93 & 3.54 \\
\hline EMPATHY 3 & 4.05 & 4.17 & 4.22 & 3.58 & 3.88 & 3.6 \\
\hline EMPATHY 4 & 4.1 & 4.04 & 4.12 & 3.77 & 4.03 & 3.6 \\
\hline EMPATHY 5 & 3.97 & 4.02 & 4.08 & 3.61 & 3.75 & 3.33 \\
\hline EMPATHY AVERAGE & 4.072 & 4.12 & 4.17 & 3.616 & 3.854 & 3.492 \\
\hline TRUST1 & 4.15 & 4.25 & 4.3 & 3.82 & 4.04 & 3.64 \\
\hline TRUST2 & 3.8 & 3.87 & 3.94 & 3.73 & 3.79 & 3.6 \\
\hline TRUST3 & 3.89 & 3.93 & 4.02 & 3.66 & 3.77 & 3.47 \\
\hline TRUST4 & 4.02 & 4.02 & 4.11 & 3.77 & 3.99 & 3.53 \\
\hline TRUST AVERAGE & 3.965 & 4.018 & 4.093 & 3.745 & 3.898 & 3.56 \\
\hline CONVENIENCE1 & 4.06 & 4.22 & 4.12 & 3.44 & 3.56 & 3.24 \\
\hline CONVENIENCE2 & 4.08 & 4.16 & 4.15 & 3.71 & 3.98 & 3.62 \\
\hline CONVENIENCE3 & 4.12 & 4.25 & 4.26 & 3.74 & 3.94 & 3.65 \\
\hline CONVENIENCE4 & 4.06 & 4.11 & 4.15 & 3.76 & 3.99 & 3.56 \\
\hline CONVENIENCE5 & 3.93 & 3.85 & 4.06 & 3.82 & 3.86 & 3.73 \\
\hline CONVENIENCE6 & 3.87 & 3.85 & 3.98 & 3.63 & 3.71 & 3.53 \\
\hline CONVENIENCE AVERAGE & 4.02 & 4.073 & 4.12 & 3.683 & 3.84 & 3.555 \\
\hline TECHNOLOGICAL1 & 4.15 & 4.22 & 4.14 & 3.8 & 4 & 3.73 \\
\hline TECHNOLOGICAL2 & 4.05 & 4.12 & 4.06 & 3.57 & 3.94 & 3.57 \\
\hline TECHNOLOGICAL3 & 4.1 & 4.24 & 4.16 & 3.69 & 4.02 & 3.66 \\
\hline TECHNOLOGICAL4 & 4.18 & 4.2 & 4.08 & 3.65 & 3.86 & 3.53 \\
\hline $\begin{array}{l}\text { TECHNOLOGICAL } \\
\text { AVERAGE }\end{array}$ & 4.12 & 4.195 & 4.11 & 3.678 & 3.955 & 3.623 \\
\hline CULTURAL1 & 3.97 & 3.89 & 4.02 & 3.48 & 3.73 & 3.43 \\
\hline CULTURAL2 & 4.32 & 4.32 & 4.48 & 3.76 & 3.94 & 3.62 \\
\hline CULTURAL3 & 4.09 & 4.08 & 4.26 & 3.57 & 3.91 & 3.62 \\
\hline
\end{tabular}




\begin{tabular}{|l|c|c|c|c|c|c|} 
CULTURAL4 & 4.14 & 4.11 & 4.29 & 3.66 & 3.94 & 3.62 \\
\hline CULTURAL5 & 4.18 & 4.18 & 4.28 & 3.89 & 4.01 & 3.72 \\
\hline CULTURAL AVERAGE & $\mathbf{4 . 1 4}$ & $\mathbf{4 . 1 1 6}$ & $\mathbf{4 . 2 6 6}$ & $\mathbf{3 . 6 7 2}$ & $\mathbf{3 . 9 0 6}$ & $\mathbf{3 . 6 0 2}$ \\
\hline MARKETING MIX 1 & 4.19 & 4.09 & 4.26 & 3.51 & 3.87 & 3.47 \\
\hline MARKETING MIX 2 & 4.07 & 4.16 & 4.31 & 3.65 & 3.83 & 3.51 \\
\hline MARKETING MIX 3 & 4.22 & 4.26 & 4.32 & 3.66 & 4.06 & 3.63 \\
\hline MARKETING MIX 4 & 4.19 & 4.35 & 4.32 & 3.67 & 3.95 & 3.53 \\
\hline MARKETING MIX 5 & 4.11 & 4.15 & 4.25 & 3.6 & 3.87 & 3.46 \\
\hline MARKETING MIX 6 & 4.13 & 4.24 & 4.32 & 3.6 & 3.89 & 3.56 \\
\hline MARKETING MIX 7 & 4.08 & 4.13 & 4.23 & 3.56 & 3.75 & 3.44 \\
\hline MARKETING MIX 8 & 3.99 & 4.12 & 4.16 & 3.53 & 3.72 & 3.22 \\
\hline $\begin{array}{l}\text { MARKETING MIX } \\
\text { AVERAGE }\end{array}$ & $\mathbf{4 . 1 2 3}$ & $\mathbf{4 . 1 8 8}$ & $\mathbf{4 . 2 7 1}$ & $\mathbf{3 . 5 9 8}$ & $\mathbf{3 . 8 6 8}$ & $\mathbf{3 . 4 7 8}$ \\
\hline OVERALL SATISFACTION 1 & 4.02 & 4.2 & 4.2 & 3.5 & 3.74 & 3.44 \\
\hline OVERALL SATISFACTION 2 & 4.17 & 4.2 & 4.25 & 3.46 & 3.57 & 3.31 \\
\hline $\begin{array}{l}\text { OVERALL SATISFACTION } \\
\text { AVERAGE }\end{array}$ & $\mathbf{4 . 0 9 5}$ & $\mathbf{4 . 2}$ & $\mathbf{4 . 2 2 5}$ & $\mathbf{3 . 4 8}$ & $\mathbf{3 . 6 5 5}$ & $\mathbf{3 . 3 7 5}$ \\
\hline LOYALTY1 & 4.16 & 4.18 & 4.22 & 3.66 & 3.93 & 3.61 \\
\hline LOYALTY2 & 4.13 & 4.11 & 4.15 & 3.61 & 3.98 & 3.57 \\
\hline LOYALTY3 & 4.15 & 4.15 & 4.21 & 3.62 & 3.94 & 3.51 \\
\hline LOYALTY4 & 4.16 & 4.15 & 4.23 & 3.68 & 3.86 & 3.66 \\
\hline LOYALTY5 & 4.09 & 4.11 & 4.21 & 3.67 & 3.87 & 3.62 \\
\hline $\begin{array}{l}\text { OVERALL LOYALTY } \\
\text { AVERAGE }\end{array}$ & $\mathbf{4 . 1 3 8}$ & $\mathbf{4 . 1 4}$ & $\mathbf{4 . 2 0 4}$ & $\mathbf{3 . 6 4 8}$ & $\mathbf{3 . 9 1 6}$ & $\mathbf{3 . 5 9 4}$ \\
\hline
\end{tabular}

In the above table bank wise mean statistics or averages are given for each variable and for overall construct. By analyzing this table, we can easily compare performance of each banks with other.

\section{MEAN STATISTICS: SECTOR WISE AVERAGE STATISTICS}

TABLE VII SECTOR WISE AVERAGE STATISTICS

\begin{tabular}{|l|c|c|}
\hline \multicolumn{1}{|c|}{ Particulars } & OVERALL PRIVATE & OVERALL PUBLIC \\
\hline TANGIBILITY 1 & 4.36 & 3.83 \\
\hline TANGIBILITY 2 & 4.13 & 3.86 \\
\hline TANGIBILITY 3 & 4.17 & 3.88 \\
\hline TANGIBILITY 4 & 4.22 & 3.85 \\
\hline TANGIBILITY 5 & 4.12 & 3.82 \\
\hline TANGIBILITY 6 & 4.14 & 3.82 \\
\hline TANGIBILITY AVERAGE & $\mathbf{4 . 1 9}$ & 3.84 \\
\hline RELIABILITY 1 & 4.22 & 3.79 \\
\hline RELIABILITY 2 & 4.22 & 3.72 \\
\hline RELIABILITY 3 & 4.11 & 3.59 \\
\hline RELIABILITY 4 & 4.21 & 3.70 \\
\hline RELIABILITY 5 & 4.09 & 3.58 \\
\hline RELIABILITY AVERAGE & $\mathbf{4 . 1 7}$ & 3.68 \\
\hline RESPONSIVENESS 1 & 4.05 & 2.86 \\
\hline RESPONSIVENESS 2 & 4.09 & 2.81 \\
\hline RESPONSIVENESS 3 & 4.17 & 2.74 \\
\hline RESPONSIVENESS 4 & 4.16 & 2.73 \\
\hline RESPONSIVENESS AVERAGE & $\mathbf{4 . 1 2}$ & $\mathbf{2 . 7 9}$ \\
\hline ASSURANCE 1 & 4.12 & 3.71 \\
\hline ASSURANCE 2 & 4.12 & 3.69 \\
\hline ASSURANCE 3 & 4.01 & 3.50 \\
\hline ASSURANCE 4 & 4.01 & 3.53 \\
\hline ASSURANCE 5 & 4.08 & 3.58 \\
\hline ASSURANCE AVERAGE & $\mathbf{4 . 0 7}$ & 3.60 \\
\hline EMPATHY 1 & 4.13 & 3.52 \\
\hline EMPATHY 2 & 4.22 & 3.68 \\
\hline EMPATHY 3 & 4.15 & 3.67 \\
\hline
\end{tabular}




\begin{tabular}{|c|c|c|}
\hline EMPATHY 4 & 4.09 & 3.79 \\
\hline EMPATHY 5 & 4.03 & 3.56 \\
\hline EMPATHY AVERAGE & 4.12 & 3.64 \\
\hline TRUST1 & 4.24 & 3.83 \\
\hline TRUST2 & 3.88 & 3.71 \\
\hline TRUST3 & 3.95 & 3.63 \\
\hline TRUST4 & 4.06 & 3.76 \\
\hline TRUST AVERAGE & 4.03 & 3.73 \\
\hline CONVENIENCE1 & 4.13 & 3.41 \\
\hline CONVENIENCE2 & 4.13 & 3.76 \\
\hline CONVENIENCE3 & 4.21 & 3.77 \\
\hline CONVENIENCE4 & 4.11 & 3.76 \\
\hline CONVENIENCE5 & 3.96 & 3.80 \\
\hline CONVENIENCE6 & 3.91 & 3.62 \\
\hline CONVENIENCE AVERAGE & 4.08 & 3.69 \\
\hline TECHNOLOGICAL1 & 4.16 & 3.84 \\
\hline TECHNOLOGICAL2 & 4.07 & 3.68 \\
\hline TECHNOLOGICAL3 & 4.18 & 3.77 \\
\hline TECHNOLOGICAL4 & 4.15 & 3.67 \\
\hline TECHNOLOGICAL AVERAGE & 4.14 & 3.74 \\
\hline CULTURAL1 & 3.96 & 3.53 \\
\hline CULTURAL2 & 4.38 & 3.77 \\
\hline CULTURAL3 & 4.15 & 3.69 \\
\hline CULTURAL4 & 4.19 & 3.73 \\
\hline CULTURAL5 & 4.22 & 3.87 \\
\hline CULTURAL AVERAGE & 4.18 & 3.72 \\
\hline MARKETING MIX 1 & 4.18 & 3.60 \\
\hline MARKETING MIX 2 & 4.19 & 3.65 \\
\hline MARKETING MIX 3 & 4.27 & 3.77 \\
\hline MARKETING MIX 4 & 4.30 & 3.70 \\
\hline MARKETING MIX 5 & 4.17 & 3.63 \\
\hline MARKETING MIX 6 & 4.24 & 3.67 \\
\hline MARKETING MIX 7 & 4.15 & 3.57 \\
\hline MARKETING MIX 8 & 4.10 & 3.48 \\
\hline MARKETING MIX AVERAGE & 4.20 & 3.63 \\
\hline OVERALL SATISFACTION 1 & 4.15 & 3.55 \\
\hline OVERALL SATISFACTION 2 & 4.21 & 3.44 \\
\hline OVERALL SATISFACTION AVERAGE & 4.18 & 3.50 \\
\hline LOYALTY1 & 4.19 & 3.72 \\
\hline LOYALTY2 & 4.13 & 3.70 \\
\hline LOYALTY3 & 4.17 & 3.68 \\
\hline LOYALTY4 & 4.19 & 3.72 \\
\hline LOYALTY5 & 4.14 & 3.71 \\
\hline OVERALL LOYALTY AVERAGE & 4.16 & 3.71 \\
\hline
\end{tabular}

In the above table sector wise mean statistics or averages are given for each variable and also for overall construct. By analyzing this table, we can easily compare the sector wise performance.

\section{CONCLUSION}

The study examines the perception of CRM in Indian banks. With the study researcher, he tried to establish a relationship between customer satisfaction and effective customer relationship management. The researcher concludes that for some factors, there is an important relationship between CRM and overall customer satisfaction and an increase in the customer base. Therefore, banking management encourages the implementation of CRM programs so that they can benefit from the current competitive business environment. Bank managers should ensure that banks protect customers' interests or provide guarantees against the impression that customers are interested in business, not customers. This can lead to a negative image of the customer, which can ultimately lead customers to think about changing their bank. Bank managers should be completely transparent regarding bank charges, to avoid negative verbal expression, which has proven to be a factor in changing banks. Customer relationship management contributes significantly to the profitability of banks. Therefore, Indian banks must design a potential customer relationship strategy that can identify the most profitable clients to allow for adaptive services according to their needs. They must also design a way to transfer low balance, that is, unprofitable customers to be profitable. The Bank's 
management should always support any customer relationship strategy aimed at improving the performance of banks. Customer satisfaction depends on the happiness of the staff. Therefore, management should always support employees because they represent banks before the customer. They must also be trained and trained to comply with existing CRM.

\section{REFERENCES}

[1] Ahmed, R. R., vveinhardt, J., štreimikiene, D., Ashraf, M., \& Channar, Z. A. (2017). Modified SERVQUAL model and effects of customer Attitude and technology on customer satisfaction In banking industry: mediation, moderation And conditional process analysis. Journal of Business Economics and Management , 18 (5).

[2] Bhat, S. A., Darzi, M. A., \& Parrey, S. H. (2018). Antecedents of Customer Loyalty in Banking Sector: A mediational Study. The Journal for Decision Makers , 43 (2).

[3] Bhat, S. A., Darzi, M. A., \& Parrey, S. H. (2018). Antecedents of Customer Loyalty in Banking Sector: A mediational Study. The Journal for Decision Makers , 43 (2).

[4] Bhatnagar, S., Mishra, J. K., \& Syed, A. A. (2018). Customer disloyalty in retail banking services: attitudinal and behavioural dimensions. Asia-Pacific Journal of Business Administration.
[5] Dubey, N. K., \& Sangle, P. (2018). Customer perception of CRM implementation in banking context: Scale development and validation. Journal of Advances in Management Research .

[6] Famiyeh, S., Asante-Darko, D., \& Kwar, A. (2017). Service quality, customer satisfaction, and loyalty in the banking sector: the moderating role of organizational culture. International Journal of Quality \& Reliability Management.

[7] Izogo, E. E., Reza, A., Ogba, I.-E., \& Oraedu, C. (2017) Determinants of relationship quality and customer loyalty in retail banking: evidence from Nigeria. African Journal of Economic and Management studies , 8 (2).

[8] Kant, R., \& Jaiswal, D. (2017). The impact of perceived service quality dimensions on customer satisfaction: an empirical study on public sector banks in India. International Journal of Bank Marketing, 35 (3).

[9] Sofi, M. R., \& Hakim, A. I. (2018). Customer Relationship Management as Tool to Enhance Competitive Effectiveness: Model Revisited. FIIB Business Review , 7 (3).

[10] Srinivas, D. (2018). Service Quality In Commercial Banks: A Study Of Public Sector Banks In Warangal District. Journal of Management, 5 (4).

[11] Yilmaz, V., Ari, E., \& Gürbüz, H. (2017). Investigating the relationship between service quality dimensions, customer satisfaction and loyalty in Turkish banking sector: an application of structural equation model. International Journal of Bank Marketing. 